\title{
Literature Review on Social and Organizational Acceptance of Digital Transformation
}

http://doi.org/10.21272/bel.5(4).110-117.2021

Olena Skrynnyk, ORCID: https://orcid.org/0000-0001-8300-6616

Technology manager, Modis, Stuttgart, Germany

\section{Abstract}

Enterprise digitization continues to drive the transformation of business processes and the content of human work. Despite the diachronic nature of these changes, social and organizational acceptance is not clearly determined. Therefore, the importance of researching the social attitudes in organizations towards digitalization arises. The relevance of the decision of this scientific problem consists in the increased digitalization and automation of all areas of the company. The main purpose of the research is to investigate the dominant research perspectives on the acceptance of digital changes in organizations. In order to provide the comprehensive review, the methods of bibliometric and network analysis were applied. For this purpose, publications on corresponding terms were searched, filtered, structured and analyzed with appropriate tools. Methodological tools of the research methods were supported by digital tool VosViewer. This article provides the results of the investigation of scientific publications on the topic of social and organizational acceptance of digital transformation in the economy and in the enterprises. The findings of the analysis, such as current subject fields, the contributing organizations, and related research focuses, point to a profound basis for further research, as well as the future potential of this issue. The results of the research can be useful for obtaining the overview and generalization of trends. The knowledge gained can be applied by scientists and practitioners.

Keywords: Digital Transformation, Digital Economy, Social Acceptance, Organizational Development, Organizational Culture.

JEL Classification: O33.

Cite as: Skrynnyk, O. (2021). Literature Review on Social and Organizational Acceptance of Digital Transformation. Business Ethics and Leadership, 5(4), 110-117. http://doi.org/10.21272/bel.5(4).110-117.2021.

Received: 14 October 2021

Accepted: 01 December 2021

Published: 30 December 2021

Copyright: (C) 2021 by the author. Licensee Sumy State University, Ukraine. This article is an open access article distributed under the terms and conditions of the Creative Commons Attribution (CC BY) license (https://creativecommons.org/licenses/by/4.0/).

\section{Introduction}

Various concepts as well as many approaches and solutions already applied are not only aimed at achieving certain performance, but also at measuring and evaluating it. These were used for the entire economy (Khan, 2018), in certain sectors (Ginevičius et al., 2018), in already established areas, new fields (such as eco-innovation) (Mutanov et al., 2019), (Oliinyk et al., 2018) as well as in the enterprise or its units (Bacik et al., 2019), (Dinçer et al., 2019), (Hájek et al., 2019), (Pakhnenko et al., 2018), (Peresadko et al., 2014), (Shkodra, 2019). Certainly, the conversion of such concepts, the elaboration of the approaches and the implementation of the solutions must be aligned with the transformations in the economy and technology and be consistent with the respective cycles (Bilan et al., 2019), (Vasilyeva et al., 2019). Digital transformation of business, projects, processes, and goods as an object of scientific knowledge has already been investigated in different studies (Ziyadin et al., 2020).

Since industry 4.0 has been the benchmark for leading technology in the first half of the XXI century, scientists are turning their attention to its application for the mentioned purposes. This is emphasized in the numerous studies: worldwide in the enterprises (Bilan et al., 2020), in the single sectors (Bilan et al., 2019), (Njegovanović, $2018 \mathrm{a}, \mathrm{b}$ ). One of the most important drivers in the transition to the digital economy is the factor of human. This primarily determines the degree of involvement of the participants, the depth of integration of the technology and the dynamics of its dissemination (Akpoviroro et al., 2018), (Alyoubi and Yamin, 2019), (Klochkov et al., 2016), (Rogowski, 2017), (Vargas-Hernández and Rodríguez, 2018). 


\section{Methodology and Research Methods}

To achieve more feasible bias, the bibliometric and network analysis of published research results was conducted. The effectiveness and timeliness of the methods and tools used have already been proven by the scientists, what supported the made decision. The initial search consisted of the initial data collection for selected terms and filtering the search results according to their temporal relevance and document type. It was performed in the Scopus database. Due to expected comprehensive results of the investigation, the following terms for the search were reviewed: "digital", "industry 4.0", "artificial intelligence", "social acceptance", "social adaption", "organizational adaption", "economy", "business", "enterprise" as well as "organizational development", "organizational change", "organizational culture".

Filtered out publications were books and book chapters, reviews, short survives as well as undefined document types and entries older than 5 years. The filtered results were analyzed and visualized according to the subject area, publication year and affiliation analysis. The obtained results were also used for the further network analysis. This was performed in well-known network tool VOSViewer (Van Eck and Waltman, 2017). The first tool evaluated the citations with the aim to define the main clusters. In the VOSViewer tool the keyword analysis was performed.

\section{Results}

The initial search analysis yielded 596 results. The 257 publications were filtered out. Analysis of the search results by year of publication shows a continuous increase till 2019 and then the decrease in 2020 (Figure 1).

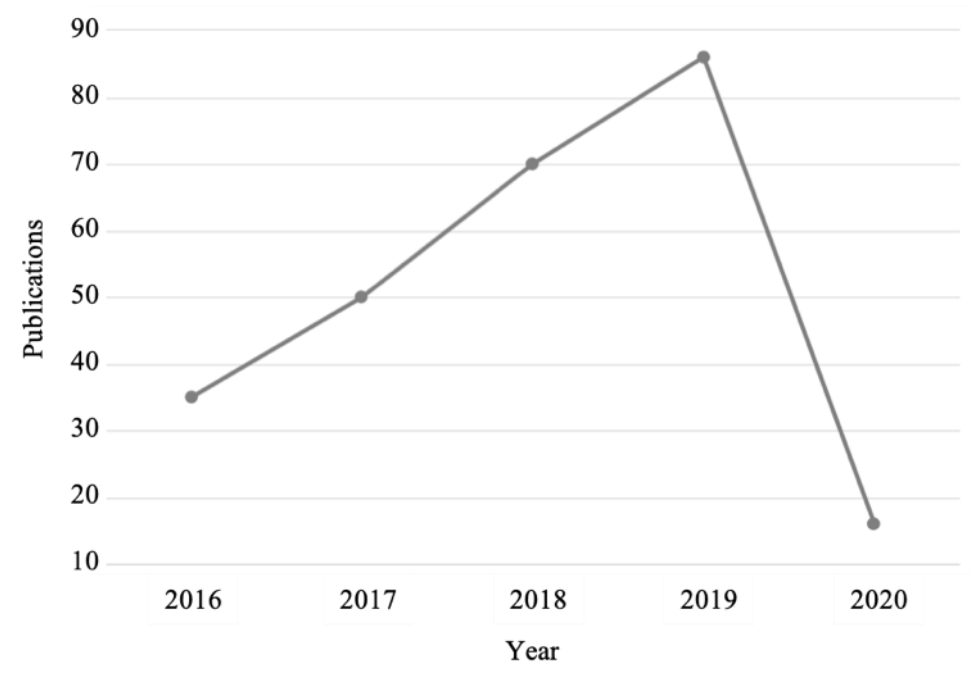

Figure 1. Publishing Trend in the Area of Social Acceptance and Organizational Development for Digital Transformation in the Economy and in Business

Source: Systematized by the author based on (Scopus, 2020)

Distribution of the number of publications is as follows: $2016-35,2017-50,2018-70,2019-86,2020-16$. Considering that the data collection was performed at the beginning of March and the number of publications was 16, assuming that the trend continues to increase, it can be stated that the scientific interest in the subject remains. Almost 65\% of all publications are published in 164 journals. Just over 35\% (91) of publications are conference proceedings. Both the articles and the conference proceedings correspond to the various scientific fields. Figure 2 shows that the largest number of papers was published in Computer Science (88). 


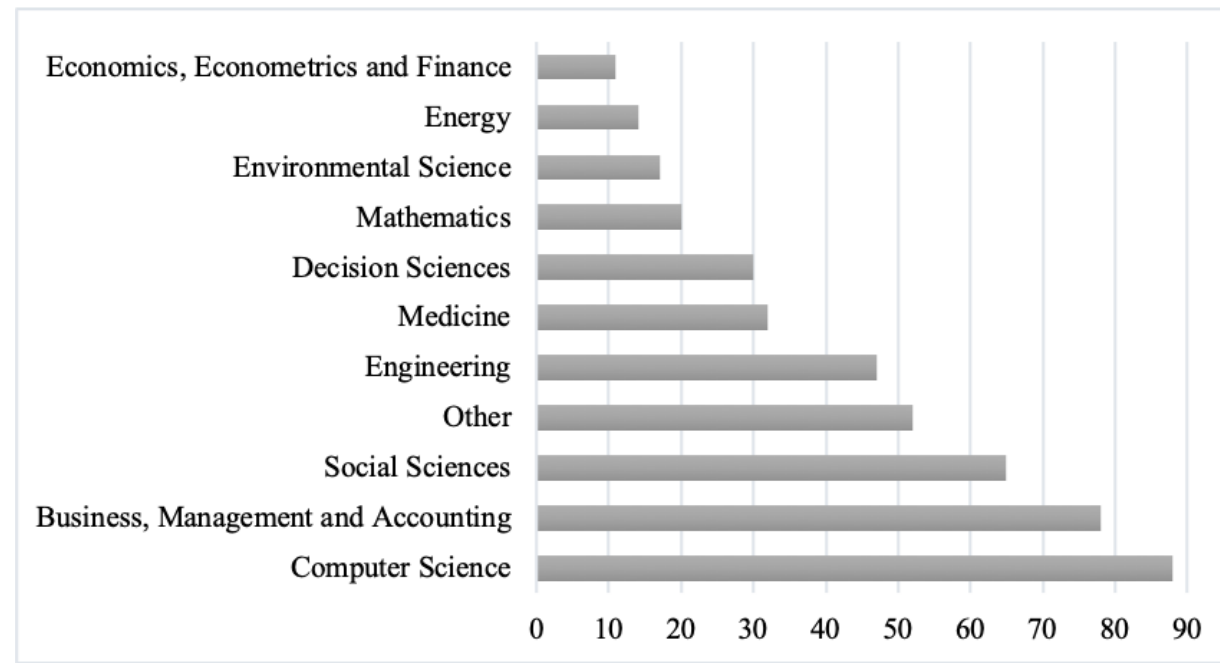

Figure 2. Scientific Fields of Citing Publications

Source: Systematized by the author based on (Scopus, 2020)

Filtering results up to the last two years $(2019,2020)$ shows that the most recently published papers belong to the same subject fields in almost the same order. The field Economics, Econometrics and Finance lands on the bottom and is replaced by Agricultural and Biological Sciences. In this study the bibliometric research was limited to author influence and affiliation statistics analysis. Since the topic is relatively new, the expected share of publications is relatively low. The number of authors was filtered to "with more than one publication". The refinement revealed that there are 20 researchers who published two and more publications to the investigated topic. The analysis of co-author groups has shown that the following scientists have published together at least two papers: Carcary, M., Doherty, E. (Carcary and Doherty, 2016), (Carcary et al., 2019); Pfeiffer, J., Gabriel, A., Gandorfer, M. (Pfeiffer et al., 2019 a, b); Renukappa, S., Suresh, S. (Abdalla et al., 2019), (Kamunda et al., 2019); Li, D., Fast-Berglund, Å., Paulin, D. (Li et al., 2019), (Li et al., 2018); Friedl, C., Reichl, J. (Azarova et al., 2019), (Friedl and Reichl, 2016); van Os, H.W.A., Herber, R., Scholtens, B. (van Os et al., 2016), (van Os et al., 2017); Mohrman, S.A., Winby, S. (Mohrman and Winby, 2018), (Pasmore et al., 2019).

Geographically, some countries have a higher density of scientific institutions that are researching the subject investigated. Table 1 lists the organizations with three or more publications corresponding to their geographical position. According to Table 1, although the largest number of publications per institution is at the University of Southern California (5) located in the USA, the largest number of research centers is in Germany. Four institutions are located here with a total of 12 publications. The other remarkable aspect is the fact that most of the contributing organizations are located in Europe. This fact is underlined by the findings of Figure 3 and Table 2: the total number of publications in Europe exceeds those in the rest of the world. Figure 3 shows the most published countries. The intensity of the colour indicates the number of publications. Countries with less than 10 publications are not marked.

Table 1. The Top 12 Contributing Organizations

\begin{tabular}{|c|c|c|c|c|c|}
\hline Organization & Location & $\begin{array}{c}\text { No. of } \\
\text { papers }\end{array}$ & Organization & $\begin{array}{c}\text { No. of } \\
\text { papers }\end{array}$ \\
\hline $\begin{array}{c}\text { University of Southern } \\
\text { California }\end{array}$ & USA & 5 & $\begin{array}{c}\text { Columbia University in the City } \\
\text { of New York }\end{array}$ & United States & 3 \\
\hline $\begin{array}{c}\text { Friedrich-Alexander- } \\
\text { Universität Erlangen- } \\
\text { Nürnberg }\end{array}$ & Germany & 3 & $\begin{array}{c}\text { Fraunhofer Institute for } \\
\text { Production Systems and Design } \\
\text { Technology IPK }\end{array}$ & Germany & 3 \\
\hline $\begin{array}{c}\text { Ludwig-Maximilians- } \\
\text { Universität München }\end{array}$ & Germany & 3 & $\begin{array}{c}\text { Rheinisch-Westfälische } \\
\text { Technische Hochschule Aachen }\end{array}$ & Germany & 3 \\
\hline $\begin{array}{c}\text { University Politehnica } \\
\text { of Bucharest }\end{array}$ & Romania & 3 & University of Groningen & Portugal & 3 \\
\hline Oulun Yliopisto & Finland & 3 & Universidade de Aveiro & Sweden & 3 \\
\hline $\begin{array}{c}\text { Swiss Federal Institute } \\
\text { of Technology EPFL, } \\
\text { Lausanne }\end{array}$ & Switzerland & 3 & Chalmers University of \\
Technology & & 3 \\
\hline
\end{tabular}

Source: Systematized by the author based on (Scopus, 2020) 


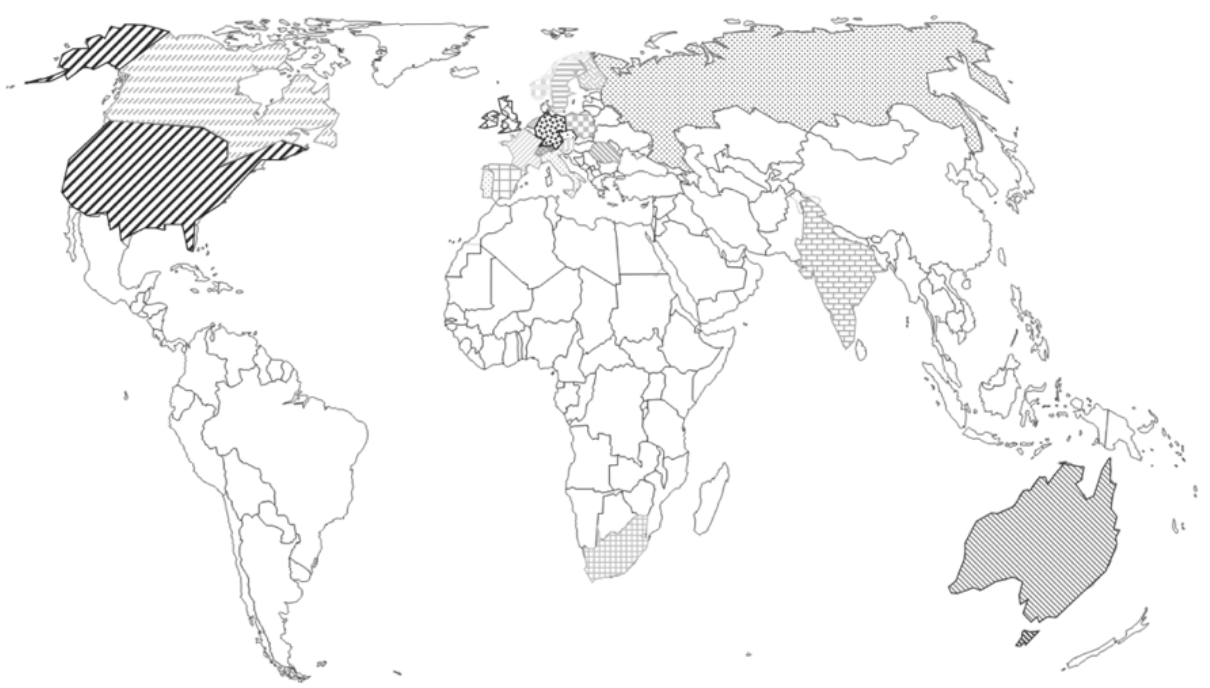

Figure 3. Geographical Locations of All Contributing Organizations

Source: Systematized by the author based on (Scopus, 2020)

Table 2. Contributing of Organizations Based on Their Geographical Regions

\begin{tabular}{|c|c|c|c|}
\hline Geographical position & $\begin{array}{l}\text { Number of papers } \\
(\% \text { contribution) }\end{array}$ & Geographical position & $\begin{array}{c}\text { Number of papers } \\
\text { (\% contribution) }\end{array}$ \\
\hline America & & \multicolumn{2}{|l|}{ Europe } \\
\hline United States & $42(16.3 \%)$ & Germany & $35(13.6 \%)$ \\
\hline Canada & $11(4.3 \%)$ & $\begin{array}{c}\text { United Kingdom } \\
\text { Switzerland } \\
\text { Netherlands } \\
\text { Sweden }\end{array}$ & $\begin{array}{c}25(9.7 \%) \\
13(5 \%) \\
11(4.3 \%) \\
11(43 \%)\end{array}$ \\
\hline Australia & $18(7 \%)$ & $\begin{array}{l}\text { Portugal } \\
\text { Romania } \\
\text { Italy }\end{array}$ & $\begin{array}{l}10(3.9 \%) \\
8(3.1 \%) \\
7(2.7 \%)\end{array}$ \\
\hline Asia & & Poland & $7(2.7 \%)$ \\
\hline India & $11(4.3 \%)$ & Finland & $6(2.3 \%)$ \\
\hline China & $5(1.9 \%)$ & France & $6(2.3 \%)$ \\
\hline Africa & & Spain & $5(1.9 \%)$ \\
\hline South Africa & $8(3.1 \%)$ & Norway & $5(1.9 \%)$ \\
\hline
\end{tabular}

Source: Systematized by the author based on (Scopus, 2020)

Since our research investigated the current and future development directions, we have performed an analysis of the mostly used keywords. It resulted in the following findings:

$>$ in total 2375 keywords were found. In order to better capture the connectivity of the terms, we have limited the selection to 79 keywords, which have at least five connections (edges) to the other keywords (nodes);

the connected keywords are organized in three large clusters with accordingly 43, 22 and 14 entries;

most connected term is "human" (occurs 35 times, with a total of 357 connections in the network).

As can be seen in Figure 4, the keywords "organizational culture", "organizational cultures", "human", "social acceptance", "digital transformation", "artificial intelligence", "organizational development", "article", "male" and "female" have the highest weightings. Considering that these keywords have great significance, it can be said that these topics are highly actual and have further potential. 


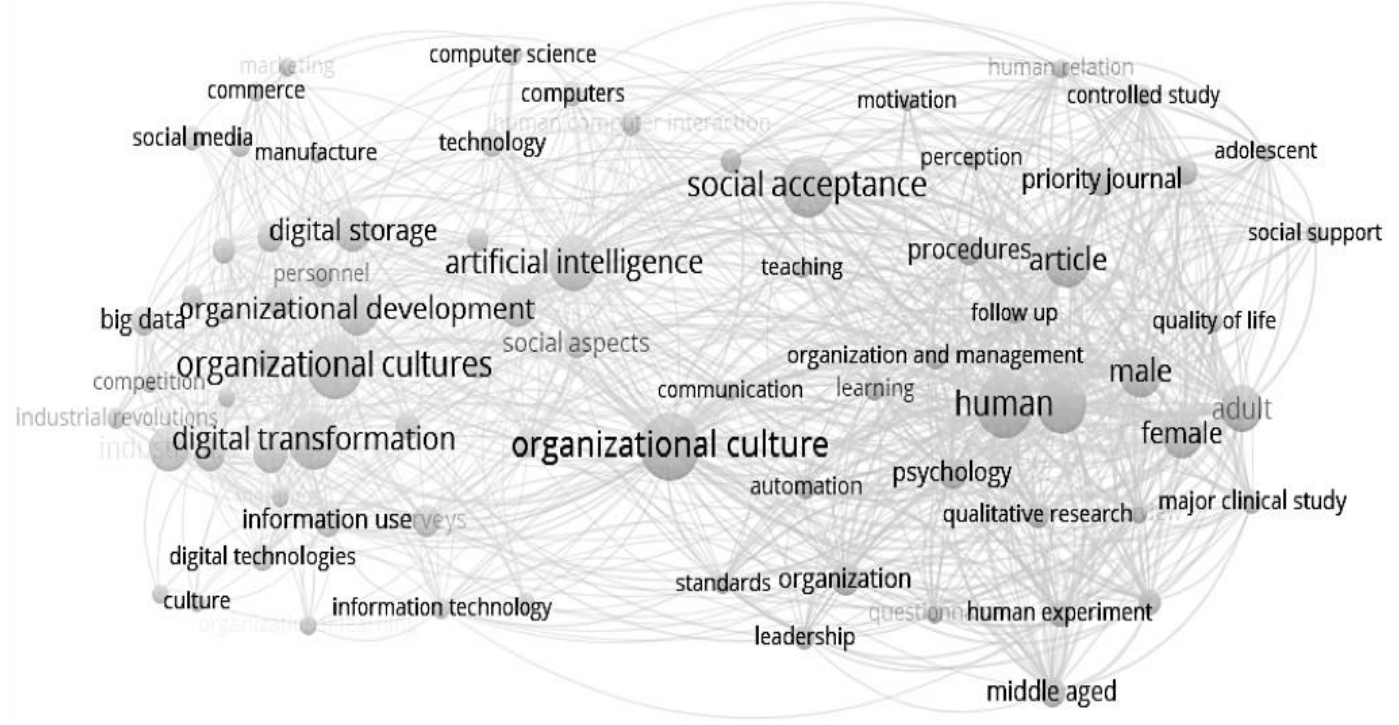

Figure 4. Network Visualization of Most Frequent Keywords

Source: Systematized by the author based on (Scopus, 2020)

The investigation for the "popularity" revealed that Klochkov, Y. et.al. was cited most frequently (54 times) (Dinçer et al., 2019).

\section{Figure 5. Visualization of Publication Networks}

Source: Systematized by the author based on (Scopus, 2020)

The subsequent publication quantity was analyzed according to the "internal connections". The citation network analysis of publications showed that 52 nodes have at least one edge (citation) to another node (publication) (Figure 5). The connected nodes form a total of 13 clusters. Five clusters with the largest number of publications are (Table 3): 
Table 3. Largest Publication Clusters

\begin{tabular}{|c|c|}
\hline Publications & $\%$ of cluster elements \\
\hline \multicolumn{2}{|l|}{ Cluster 1: Digital transformation and organizational learning } \\
\hline $\begin{array}{l}\text { Alos-Simo L., Verdu-Jover A.J., Gomez-Gras J.-M. (2017) } \\
\text { Ferreira M.J., Moreira F., Seruca I. (2017) } \\
\text { Guerini C., Minelli E.A. (2018) } \\
\text { Malik S., Chetty M., Chadhar M. (2018) } \\
\text { Moen O. (2016), Teichert R. (2019) } \\
\text { Troilo G., de Luca L.M., Guenzi P. (2017) }\end{array}$ & $2.75 \%(7)$ \\
\hline \multicolumn{2}{|l|}{ Cluster 2: Social acceptance and energy area } \\
\hline $\begin{array}{l}\text { Azarova V., Cohen J., Friedl C., Reichl J. (2019) } \\
\text { Florio P., Perera A.T.D., Coccolo S., Scartezzini J.-L. (2019) } \\
\text { Friedl C., Reichl J. (2016) } \\
\text { Schriever M., Halstrup D. (2018) } \\
\text { Stephanides P., Chalvatzis K.J., Li X., Lettice F., Guan D., Ioannidis A., Zafirakis D., } \\
\text { Papapostolou C. (2019) } \\
\text { van Os H.W.A., Herber R., Scholtens B. (2016, 2017) } \\
\text { Zaunbrecher B.S., Bexten T., Specht J.M., Wirsum M., Madlener R., Ziefle M. (2017) }\end{array}$ & $2.75 \%(7)$ \\
\hline \multicolumn{2}{|l|}{ Cluster 3: Human role for (digital) business performance } \\
\hline $\begin{array}{l}\text { Budisusetio D.H., Sule E.T., Febrian E., Yunizar (2019) } \\
\text { Davids F., van Belle J.-P. (2017) } \\
\text { Eden R., Burton-Jones A. (2018) } \\
\text { Frisk J.E., Bannister F. (2017) } \\
\text { Hartl E., Hess T. (2017) } \\
\text { Ivanov A.O. (2017), Rajanen D., Rajanen M. (2019) }\end{array}$ & $2.75 \%(7)$ \\
\hline \multicolumn{2}{|l|}{ Cluster 4: Organizational culture in context of industry 4.0} \\
\hline $\begin{array}{l}\text { Bordeleau F.-E., Mosconi E., de Santa-Eulalia L.A. (2020) } \\
\text { Madureira A., den Fartog F., Baken N. (2016) } \\
\text { Meier S., Stephenson M., Perkowski P. (2019) } \\
\text { Mohelska H., Sokolova M. (2018) } \\
\text { Mohrman S.A., Winby S. (2018) } \\
\text { Prause G., Atari S. (2017), Wilczek B. (2019) }\end{array}$ & $2.75 \%(7)$ \\
\hline \multicolumn{2}{|l|}{ Cluster 5: Digitalization and organizational management } \\
\hline $\begin{array}{l}\text { Carcary M., Doherty E. (2016) } \\
\text { Christoffels M. (2019) } \\
\text { Lobschat L., Mueller B., Eggers F., Brandimarte L., Diefenbach S., Kroschke M., Wirtz J. (2019) } \\
\text { Müller S.D., Obwegeser N., Glud J.V., Johildarson G. (2019) } \\
\text { Tronvoll B., Sklyar A., Sörhammar D., Kowalkowski C. (2020), Wiesboeck F. (2018) }\end{array}$ & $2.35 \%(6)$ \\
\hline
\end{tabular}

Source: Systematized by the author based on (Scopus, 2020)

\section{Discussion}

In this investigation the author tried to be objective and obtain the most accurate results. Nevertheless, the investigation has some limitations:

definition limitation (on the one hand, synonyms are often used for the same terms, which subsequently limits the results of the investigation; on the other hand, the issues, which only describe a certain aspect of the topic and are not identified accordingly, are also not considered);

use of only one database (the more literature sources are available, the more complete the range of results).

\section{Conclusion}

The results of our investigation provide numerous conclusions:

$>$ the issue of raising awareness of digitization among individuals, especially within society and closer the organization, remains relevant;

$>$ particularly relevant in this context are the fields of Computer Science, Business, Management and Accounting, Engineering, Social Sciences and others;

$>$ the most influential institutions in this field are located in the United States and Germany;

$>$ the tendency to focus on organizational issues (especially "organizational culture") in the context of digitization in companies and in the economy.

The gained knowledge can be used by scientists and practitioners for further research in the field of digitalization of economy of or individual business. The investigation highlighted the key points of the field of knowledge. 
Funding. The survey was supported by the Ministry of Education and Science of Ukraine and performed the results of the project "Modeling and forecasting of the socio-economic-political road map of reforms in Ukraine for the transition to a sustainable growth model" (registration number 0118U003569).

\section{References}

1. Abdalla, W., Renukappa, S., Suresh, S., \& Al-Janabi, R. (2019). Challenges for Managing Smart Cities Initiatives: An Empirical Study. Proceedings of 3rd International Conference on Smart Grid and Smart Cities, ICSGSC 2019, 10-17. [Google Scholar] [CrossRef]

2. Akpoviroro, K.S., Olalekan, A., \& Alhaji, S.A. (2018). Moderating Influence of Strategic Human Resources Management Practices on Small-Medium Firm Performance. Business Ethic and Leadership, 2(4), 99-107. [Google Scholar] [CrossRef]

3. Alyoubi, A.B. \& Yamin, M.A.Y. (2019). The impact of task technology fit on employee job performance. Marketing and Management of Innovations 4, 140-159. [Google Scholar] [CrossRef]

4. Azarova, V., Cohen, J., Friedl, C., \& Reichl, J. (2019). Designing local renewable energy communities to increase social acceptance: Evidence from a choice experiment in Austria, Germany, Italy, and Switzerland. Energy Policy 132, 1176-1183. [Google Scholar] [CrossRef]

5. Bacik, R., Kloudova, J., Gonos, J., \& Ivankova, V. (2019). Management of competitiveness and economic performance based in the V4 countries. Marketing and Management of Innovations 3, 73-88. [Google Scholar] [CrossRef]

6. Bilan, Y., Brychko, M., Buriak, A. \& Vasilyeva, T. (2019). Financial, business and trust cycles: The issues of synchronization [Ciklusi financiranja, poslovanja i povjerenja: pitanja za sinkronizaciju]. Zbornik Radova Ekonomskog Fakultet au Rijeci 37(1), 113-138. [Google Scholar] [CrossRef]

7. Bilan, Y., Đšuzmenko, Đž. \& Boiko, A. (2019). Research on the impact of industry 4.0 on entrepreneurship in various countries worldwide. Proceedings of the 33rd International Business Information Management Association Conference, IBIMA 2019: Education Excellence and Innovation Management through Vision 2020, 2373-2384. Available at: [Link]

8. Bilan, Y., Rubanov, P., Vasylieva, T., \& Lyeonov, S. (2019). The influence of industry 4.0 on financial services: Determinants of alternative finance development [Wpływ przemysłu 4.0 na usługi finansowe: determinanty rozwoju alternatywnych finansów]. Polish Journal of Management Studies, 19(1), 70-93. [Google Scholar] [CrossRef]

9. Carcary, M. \& Doherty, E. (2016). "The digital wild west": Managing the risks of digital disruption. Proceedings of the European Conference on IS Management and Evaluation, ECIME, 29-36. [Google $\underline{\text { Scholar] }}$

10. Carcary, M., Doherty, E., \& Conway, G. (2019). Personal data protection (Pdp): A conceptual framework for organisational management of personal data in the digital context. European Conference on Information Warfare and Security, ECCWS 2019(July), 87-96. [Google Scholar]

11. Dinçer, H., Yüksel, S., Korsakiene, R., Raišiene, A.G. \& Bilan, Y. (2019). IT2 hybrid decision-making approach to performance measurement of internationalized firms in the Baltic States. Sustainability (Switzerland), 11(2), 296. [Google Scholar]

12. Friedl, C. \& Reichl, J. (2016). Realizing energy infrastructure projects - A qualitative empirical analysis of local practices to address social acceptance. Energy Policy, 89, 184-193. [Google Scholar] [CrossRef]

13. Ginevičius, R., Gedvilaitè, D., Stasiukynas, A., \& Čepel, M. (2018). Integrated assessment of the socioeconomic systems' development. Economics and Sociology, 11(1), 11-21. [Google Scholar] [CrossRef]

14. Hájek, P., Zhunissova, G., Oralbaeva, Z., Zhidebekkyzy, A., \& Baidildina, A. (2019). Competitiveness and Economic Profit Analysis of Kazakhstan's Poultry Companies. Journal of International Studies, 12(2), 147-164. [Google Scholar] [CrossRef]

15. Kamunda, A., Renukappa, S., \& Suresh, S. (2019). Knowledge management in the UK water industry. Proceedings of the European Conference on Knowledge Management, ECKM 2019, 1, 593-600. [Google Scholar]

16. Khan, M J.H. (2018). The Effectiveness of Entrepreneurial Activities for Economic Development: A Route to Innovation and Job Generation. SocioEconomic Challenges, 2(2), 32-40. [Google Scholar] [CrossRef]

17. Klochkov, Y., Gazizulina, A., \& Golovin, N. (2016). Assessment of organization development speed based on the analysis of standards efficiency. Proceedings - 2nd International Symposium on Stochastic Models in Reliability Engineering, Life Science, and Operations Management, SMRLO 2016, 530-532. [Google $\underline{\text { Scholar] }}$ 
18. Li, D., Fast-Berglund, Å., \& Paulin, D. (2019). Current and future Industry 4.0 capabilities for information and knowledge sharing: Case of two Swedish SMEs. International Journal of Advanced Manufacturing Technology, 105(9), 3951-3963. [Google Scholar] [CrossRef]

19. Li, D., Paulin, D., Fast-Berglund, Å., Gullander, P., \& Bligård, L.-O. (2018). Supporting individual needs for intra-organisational knowledge sharing activities in pre-industry 4.0 SMEs. Proceedings of the International Conference on Intellectual Capital, Knowledge Management and Organisational Learning, ICICKM 2018-November, 160-170. [Google Scholar]

20. Mohrman, S.A. \& Winby, S. (2018). Working toward sustainable development: Consulting to the ecosystem. Research in Organizational Change and Development, 26, 1-45. [Google Scholar] [CrossRef]

21. Mutanov, G., Ziyadin, S., \& Shaikh, A. (2019). Graphic model for evaluating the competitiveness and ecoefficiency of eco-innovative projects. Entrepreneurship and Sustainability Issues, 6(4), 2136-2158. [Google Scholar] [CrossRef]

22. Njegovanović, A. (2018). Digital Financial Decision with a View of Neuroplasticity /Neurofinancy/ Neural Networks. Financial Markets, Institutions and Risks, 2(4), 82-91. [Google Scholar] [CrossRef]

23. Njegovanović, A. (2018). Artificial Intelligence: Financial Trading and Neurology of Decision. Financial Markets, Institutions and Risks, 2(2), 58-68. [Google Scholar] [CrossRef]

24. Oliinyk, V., Kozmenko, O., Wiebe, I., \& Kozmenko, S. (2018). Optimal control over the process of innovative product diffusion: The case of sony corporation. Economics and Sociology, 11(3), 265-285. [Google Scholar] [CrossRef]

25. Pakhnenko, O., Liuta, O. \& Pihul, N. (2018). Methodological approaches to assessment of the efficiency of business entities activity. Business and Economic Horizons, 14(1), 143-151. [Google Scholar] [CrossRef]

26. Pasmore, W., Winby, S., Mohrman, S.A., \& Vanasse, R. (2019). Reflections: Sociotechnical Systems Design and Organization Change. Journal of Change Management, 19(2), 67-85. [Google Scholar] [CrossRef]

27. Peresadko, G.O., Kovalenko, E.V., \& Kulyk, L.A. (2014). Mechanisms of investing into innovative projects of enterprises. Actual Problems of Economics, 160(1), 184-187. [Google Scholar]

28. Pfeiffer, J., Gabriel, A., \& Gandorfer, M. (2019). Social acceptance of digital livestock farming technologies: The dairy sector. Precision Livestock Farming 2019 - Papers Presented at the 9th European Conference on Precision Livestock Farming, ECPLF 2019, 364-369. [Google Scholar]

29. Pfeiffer, J., Schleicher, S., Gabriel, A., \& Gandorfer, M. (2019). Gesellschaftliche akzeptanz von Digitalisierung in der Landwirtschaft [Social acceptance of digitalization in agriculture]. Lecture Notes in Informatics (LNI). Proceedings - Series of the Gesellschaft fur Informatik (GI) P-287, 151-154. [Google Scholar]

30. Rogowski, R. (2017). Theoretical Reasons for Economic Sociology. SocioEconomic Challenges, 1(4), 45-49. [Google Scholar] [CrossRef]

31. Shkodra, J. (2019). Financial performance of microfinance institutions in Kosovo. Journal of International Studies, 12(3), 38-47. [Google Scholar] [CrossRef]

32. Vasilyeva, T., Kuzmenko, O., Bozhenko, V., \& Kolotilina, O. (2019). Assessment of the dynamics of bifurcation transformations in the economy. CEUR Workshop Proceedings 2422, 134-146. [Google Scholar

33. Van Eck, N.J. \& Waltman, L. (2017). Citation-based clustering of publications using CitNetExplorer and VOSviewer. Scientometrics, 111(2), 1053-1070. [Google Scholar] [CrossRef]

34. van Os, H.W.A., Herber, R., \& Scholtens, B. (2016). Subsurface activities and decision support systems: An analysis of the requirements for a social acceptance-motivated decision support system. Environmental Impact Assessment Review 60, 176-185. [Google Scholar]

35. van Os, H.W.A., Herber, R., \& Scholtens, B. (2017). Modular evaluation method for subsurface activities (MEMSA). A novel approach for integrating social acceptance in a permit decision-making process for subsurface activities. Environmental Impact Assessment Review, 64, 97-122. [Google Scholar]

36. Vargas-Hernández, J.G. \& Rodríguez, C.R.F. (2018). Leadership Styles as a Challenge to Generate Innovation Environments in the Companies of the 21st Century. Business Ethics and Leadership, 2(4), 64-73. [Google Scholar] [CrossRef]

37. Ziyadin, S., Suieubayeva, S., \& Utegenova, A. (2020). Digital Transformation in Business. Lecture Notes in Networks and Systems 84, 408-415. [Google Scholar] [CrossRef] 